\title{
Role of stress peptides during human pregnancy and labour
}

\author{
Edward W. Hillhouse* and Dimitris K. Grammatopoulos \\ The Sir Quinton Hazell Molecular Medicine Research Centre, Department of Biological \\ Sciences, University of Warwick, Coventry CV4 7AL, UK
}

\begin{abstract}
Premature birth is the major source of perinatal death and disability. Furthermore, the intrauterine health of the baby is important for preventing certain adult diseases. However, the molecular mechanisms driving the onset of human labour remain uncertain, although several key players have been identified. It is becoming clear that there are many pathways to parturition in humans. Stress peptides, in particular placental corticotrophin releasing hormone $(\mathrm{CRH})$ and possibly the related peptide urocortin, appear to play important roles throughout pregnancy. Plasma $\mathrm{CRH}$ is a predictor of the duration of human gestation. During most of pregnancy, $\mathrm{CRH}$, acting via specific $\mathrm{CRH}$ receptor subtypes, plays a 'protective' role by promoting myometrial quiescence via the generation of CAMP and CGMP, and upregulation of nitric oxide synthase expression. At term, myometrial contractility is enhanced by a complex series of molecular switches, involving the upregulation of oxytocin receptor expression and crosstalk between the oxytocin and $\mathrm{CRH}$ receptors. This results in protein kinase $\mathrm{C}$-induced phosphorylation of specific $\mathrm{CRH}$ receptor subtypes, with subsequent desensitization and a shift in the intracellular microenvironment to enhance contractility. $\mathrm{CRH}$ /urocortin, via specific receptor isoforms, is now able to activate $\mathrm{Gq}$ and potentially enhance the oxytocin-driven generation of inositol triphosphate. In addition, $\mathrm{CRH}$ /urocortin, via specific CRH receptor subtypes, may generate prostaglandins from the fetal membranes and decidua, play a role in placental vasodilatation and participate in fetal adrenal function and organ maturation. These peptides and receptors are phylogenetically ancient and well preserved across species. They may have evolved as a mechanism to protect against the 'stress' of premature birth.
\end{abstract}

\begin{abstract}
During gestation, the uterus remains in a state of quiescence to ensure successful maturation of the fetus. At term, the cervix dilates and the uterus switches from quiescence to a state of co-ordinated contractility. The molecular mechanisms underlying these complex physiological events remain elusive. In up to $10 \%$ of human pregnancies, the mechanisms controlling these processes are altered in such a way that pre-term birth takes place. Although parturition in humans appears to be unique, there are features that are preserved across species. One such feature is the activation of the maternal and fetal hypothalamo-pituitary-adrenal axes, the primary function of which is to control the response of the body to stress (Liggins, 1976; Thorburn and Challis, 1979; Challis et al., 2000). A key component of this axis is corticotrophin releasing hormone (CRH), a 41 amino acid hypothalamic peptide that helps to co-ordinate the endocrine, autonomic, behavioural, cardiovascular and immune responses to stress. Recently, it has become clear that $\mathrm{CRH}$ is part of a larger family of stress-related peptides
\end{abstract}

*Correspondence address: The Office of the Dean, The Medical School, The University of Leeds LS2 9JT, UK

Email: e.w.hillhouse@leeds.ac.uk that includes the urocortins (Vaughan et al., 1995; Donaldson et al., 1996; Lewis et al., 2001; Reyes et al., 2001). These related peptides mediate their effects on the target cells via seven helical transmembrane domain receptors that transduce their signal through stimulation of various $G$ proteins.

\section{Plasma CRH and urocortin}

$\mathrm{CRH}$ is synthesized by fetomaternal tissues (Petraglia et al., 1987; Riley et al., 1991; Warren and Silverman, 1995; Clifton et al., 1998; Gravanis et al., 2001) and is secreted into the maternal circulation during gestation, where concentrations increase exponentially as pregnancy progresses (Goland et al., 1986; Campbell et al., 1987). It has been suggested that there is a 'CRH placental clock' which is active from the early stages of human pregnancy and determines the duration of gestation and the timing of parturition and delivery (McLean et al., 1995). Interestingly, patients presenting in pre-term labour have high concentrations of circulating CRH (Campbell et al., 1987; Sasaki et al., 1987; Warren et al., 1992). The utility of plasma CRH measurement in the prediction of pre-term labour has not 
yet been fully elucidated. However, it can be used to identify patients presenting in pre-term labour who will deliver within the next 24-48 h (Korebrits et al., 1998). In the maternal circulation, $\mathrm{CRH}$ attaches to a binding protein (Behan et al., 1989; Potter et al., 1991) and circulates as a dimerized binding protein-ligand complex. Patients at risk of undergoing pre-term labour have significantly increased maternal concentrations of $\mathrm{CRH}$, lower concentrations of $\mathrm{CRH}$ binding protein and a reduction in the $\mathrm{CRH}$ binding protein-CRH dimer complex (Hobel et al., 1999). Thus, free concentrations of $\mathrm{CRH}$ are increased in the maternal circulation and may play a role in the pathophysiological events leading to pre-term labour. Urocortin is also expressed in human placenta, fetal membranes and uterine tissues (Petraglia et al., 1996; Clifton et al., 2000). Urocortin is detectable at low concentrations in maternal plasma from several weeks of gestation but the concentrations do not change during gestation (Clifton et al., 2000).

The placental expression of the $\mathrm{CRH}$ gene and secretion of biologically active $\mathrm{CRH}$ is under the control of a number of factors including nitric oxide, progesterone, catecholamines, oxytocin, cytokines and glucocorticoids (Challis et al., 2000). The key interaction appears to be that between cortisol and progesterone, as the latter inhibits $\mathrm{CRH}$ gene expression, an effect that can be reversed by cortisol (Karalis et al., 1996).

\section{Possible roles of $\mathrm{CRH}$ and related peptides during pregnancy}

The precise biological functions of $\mathrm{CRH}$ and related peptides during pregnancy are unknown. However, it is known that a series of molecular events mediated by autocrine, endocrine and paracrine actions of $\mathrm{CRH}$, and possibly urocortin, is activated during pregnancy and at term to prepare the fetus and uterus for parturition. A number of hypotheses, which are not mutually exclusive, have emerged: (i) $\mathrm{CRH}$ and urocortin may regulate myometrial contractility/quiescence via a direct action on myometrial cells and, thus, play a role in the prevention of premature labour and in the onset of term labour (Grammatopoulos and Hillhouse, 1999); (ii) CRH and urocortin may influence myometrial contractility indirectly; for example, $\mathrm{CRH}$ stimulates prostaglandin production by the fetal membranes and placenta (Jones and Challis, 1989); (iii) $\mathrm{CRH}$ or urocortin or both may play a role in regulation of placental blood flow (Clifton et al., 1995; Leitch et al., 1998). The vasodilatory effects of both peptides appear to be mediated by a nitric oxide/cGMP-dependent pathway with urocortin being the most potent vasodilator; and (iv) $\mathrm{CRH}$ may play an important role in the regulation of fetal adrenal function and, hence, maturation of various organ systems (Randeva et al., 2001). These mechanisms may have evolved to protect the fetus against environmental stress. However, under certain circumstances, it is possible that fetal or maternal stress could play an important role in initiating a cascade of intracellular signals leading to preterm labour.

\section{The $\mathrm{CRH}$ receptor family}

The CRH-related family of peptides exert physiological responses that are co-ordinated by the expression of two receptors, CRHR1 (Chen et al., 1993) and CRHR2 (Lovenberg et al., 1995), encoded by separate genes mapped to human chromosomes 17 (Polymeropoulos et al., 1995) and 7 (Meyer et al., 1997), respectively. These receptors belong to the group II subfamily of seven helical transmembrane spanning domain $G$ protein-coupled receptors, which includes receptors for calcitonin, vasoactive intestinal peptide and parathyroid hormone. The CRHR1 binds CRH and related peptides (urocortin, urotensin and sauvagine) with high affinity. CRHR2 binds urocortin with higher affinity than the other $\mathrm{CRH}$-like peptides and also binds the newly identified urocortin 2 and urocortin 3 peptides, indicating that these may be the natural or preferred ligands (Vaughan et al., 1995; Lewis et al., 2001; Reyes et al., 2001). CRHR1 shares $70 \%$ similarity with CRHR2 and both receptors are present in structurally distinct isoforms. The CRHR1 gene expresses four known subtypes, $1 \alpha, 1 \beta, 1 \mathrm{c}$ and $1 \mathrm{~d}$ (for references, see Grammatopoulos and Hillhouse, 1999; Grammatopoulos et al., 1999), produced by differential splicing of exons 3, 6 and 13 (Fig. 1). The CRHR2 gene expresses three known subtypes, $2 \beta, 2 \gamma$ and $2 \alpha$ (for references, see Hillhouse and Grammatopoulos, 2001), that are produced by the use of alternate 5' exons (Fig. 2) and, hence, differ only at the $\mathrm{N}$ terminus that forms part of the first extracellular domain. The expression of type I CRH receptors is controlled by a single promoter and use of differential splicing, whereas the type 2 receptor uses multiple promoters in addition to alternative splicing (R. Catalano, D. K. Grammatopoulos and E. W. Hillhouse, unpublished).

\section{Expression of $\mathrm{CRH}$ receptors in fetomaternal tissues}

Non-pregnant human myometrium expresses three $\mathrm{CRH}$ receptor subtypes, namely $1 \alpha, 1 \beta$ and $2 \beta$. As pregnancy progresses, the myometrium starts to express the $2 \alpha$ receptor. In addition, at term the myometrium expresses the 1c and 1d receptor subtypes (Grammatopoulos et al., 1998, 2000), indicating a possible functional role for these receptor subtypes at the end of pregnancy. The molecular mechanisms regulating the expression of the receptor subtypes remain unknown but presumably involve fine interplay between the gene promoters and the mRNA splicing enzymes. Furthermore, these observations imply that the biological actions of $\mathrm{CRH}$ and urocortin in myometrium during the different stages of pregnancy are mediated via different $\mathrm{CRH}$ receptor subtypes. The syncytiocytotrophoblasts of the placenta and the fetal membranes express the $1 \alpha, 1 \mathrm{c}, 1 \mathrm{~d}$ and $2 \beta$ subtypes (Karteris et al., 1998; Florio et al., 2000), and the fetal adrenal glands express both the $1 \alpha$ and $2 \alpha$ subtypes (Smith et al., 1998; Karteris et al., 2001). 


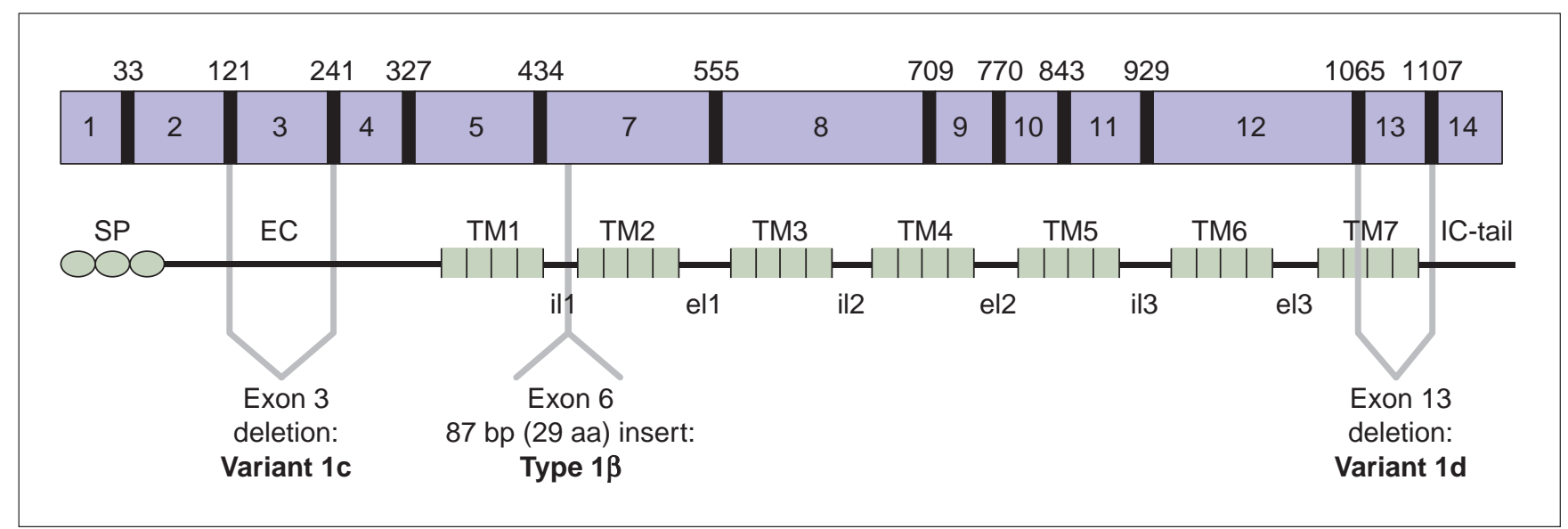

Fig. 1. Schematic representation of the mRNA encoding corticotrophin releasing hormone receptor $1 \alpha(C R H R 1 \alpha)$. Different receptor isoforms are generated by alternative exon splicing. SP: signal peptide; TM: transmembrane domain; EC: extracellular domain; il: intracellular loop; el: extracellular loop; IC-tail: intracellular tail; aa: amino acids.

(a)

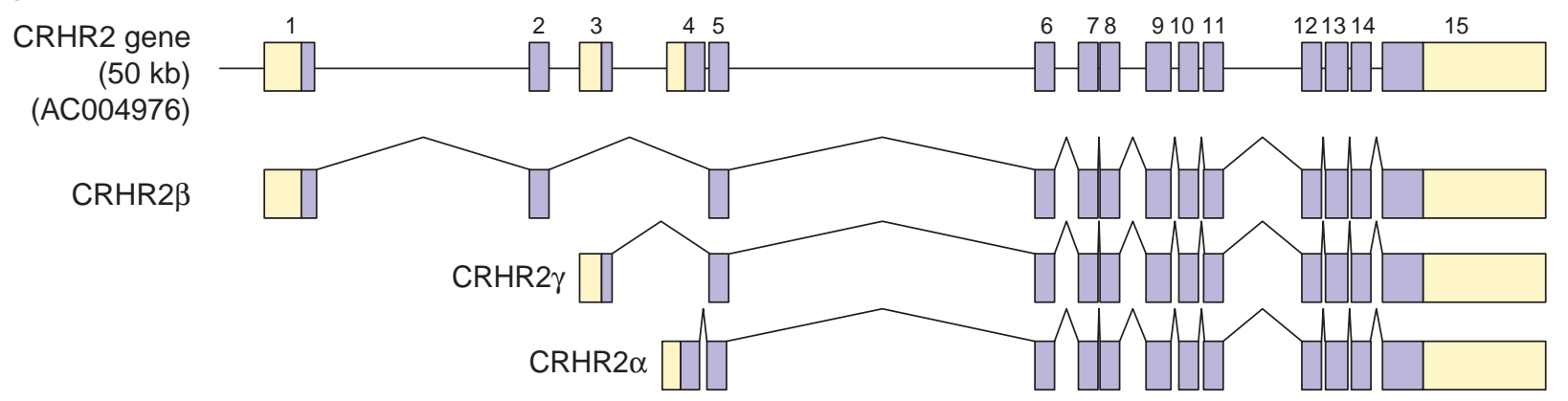

(b)

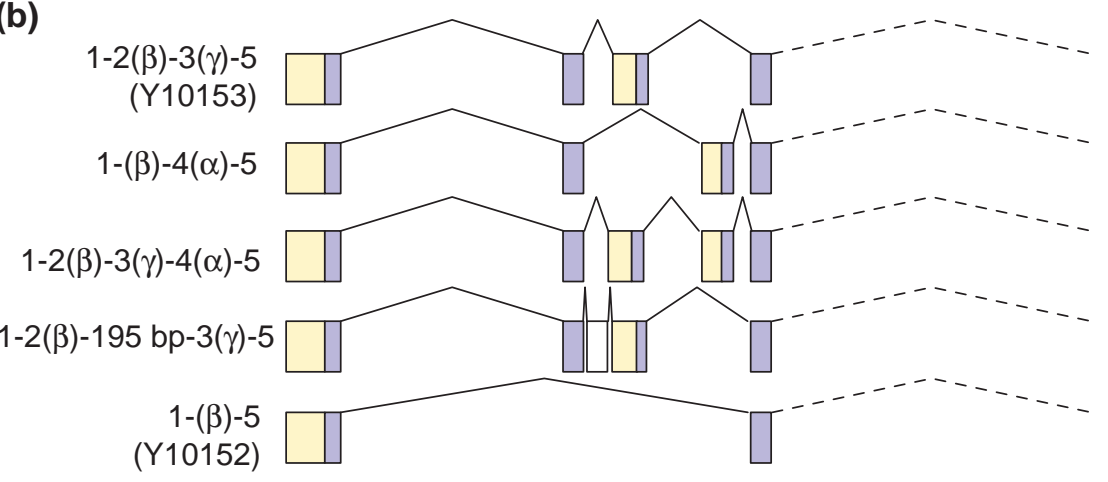

Fig. 2. (a) Schematic representation of the human corticotrophin releasing hormone receptor 2 (CRHR2) gene. Exons are indicated by purple boxes and 5' $-3^{\prime}$ untranslated regions are indicated by yellow boxes. The CRHR2 gene spans 50 kb and consists of 15 exons. The distances between the exons are drawn to scale but not in relation to exon size. Functional transcripts are indicated for the $\beta, \gamma$ and $\alpha$ receptors. (b) Confirmed non-functional transcripts arising from aberrant splicing.

\section{Roles of CRH and urocortin in the control of myometrial contactility during pregnancy}

In human myometrium, $\mathrm{CRH}$ activates multiple classes of $\mathrm{G}$ protein, namely $\mathrm{Gs} \alpha, \mathrm{Gi} \alpha, \mathrm{Go} \alpha, \mathrm{Gq} \alpha$ and $\mathrm{Gz} \alpha$, indicating that it may signal via multiple signalling pathways. To date, our work has focused on the Gs $\alpha$ and Gq $\alpha$ systems. In the non-pregnant state, the $\mathrm{CRH}$ receptors do not couple to the adenylate cyclase system (Grammatopoulos et al., 1994). However, during pregnancy, there is coupling 
to Gs $\alpha$ and the adenylate cyclase system leading to production of cAMP that shifts the balance of the intracellular microenvironment towards myometrial quiescence. This effect of $\mathrm{CRH}$ is reinforced by stimulation of other intracellular signalling pathways that are also involved in the relaxation of myometrium during pregnancy. For example, $\mathrm{CRH}$ activates membrane-bound guanyl cyclase via a protein kinase $\mathrm{A}$ (PKA)-dependent mechanism leading to production of cGMP and activation of the nitric oxide system. In addition, CRH stimulates activity of the soluble form of guanyl cyclase via a PKA-independent mechanism that involves upregulation of the constitutive form of nitric oxide synthase (Aggelidou et al., 2002). Furthermore, $\mathrm{CRH}$ can block the cytokine-induced activation of myometrial prostaglandin production (Grammatopoulos and Hillhouse, 1999) that has been proposed as a mechanism for infection-induced pre-term labour (Pollard and Mitchell, 1996).

In pre-term myometrium, $\mathrm{CRH}$ activates both the short $(45 \mathrm{kDa})$ and the long $(52 \mathrm{kDa})$ form of the Gs $\alpha$ protein, whereas it has no effect on Gq $\alpha$ protein activation. This pattern of $G$ protein activation favours generation of intracellular cAMP and promotion of myometrial quiescence. However, at term a significant change takes place; $\mathrm{CRH}$ now activates only the short form of Gs $\alpha$ protein but, more importantly, also activates the Gq $\alpha$ protein (H. Randeva, D. K. Grammatopoulos and E. W. Hillhouse, unpublished). The precise function of the different isoforms of the Gs $\alpha$ proteins remains poorly characterized and, therefore, the exact physiological significance of these events remains to be determined. However, it would seem likely that before term, CRH plays a 'protective' role for the myometrium by preventing uterine contractions. If this is true, then the increased concentrations of maternal circulating $\mathrm{CRH}$ in abnormal pregnancy states (Goland et al., 1995) might be a response to an abnormal or premature labouring process to prevent the development of premature contractions and protect the fetus from expulsion. Activation of the Gq $\alpha$ protein with subsequent stimulation of the phospholipase C/inositol triphosphate pathway supports the contention that there is a shift in the role of CRH towards term to enhance myometrial contractility and labour. However, it is important to realise that these data have been obtained using biopsies from the lower segment of the uterus and that there may be region-specific changes in $\mathrm{CRH}$ receptor subtypes in the uterus during pregnancy and labour. This may be particularly important in the fundus, which plays an essential role in uterine activity and contractions.

\section{Myometrial intracellular crosstalk between oxytocin and $\mathrm{CRH}$ receptors}

Oxytocin is a powerful uterotonin and is thought to play a role in the mechanisms leading to parturition. However, this view has been questioned by observations of mice in which the oxytocin gene was inactivated by homologous recombination. These studies showed that oxytocin is essential for lactation but not for normal parturition in mice (Nishimori et al., 1996; Young et al., 1996). However, in humans the oxytocin system appears to participate in the mechanisms driving normal and abnormal labour, as the oxytocin receptor antagonist Atosiban induces uterine quiescence in both normal and pre-term labour (Romero et al., 2000; Valenzuela et al., 2000). Further support for this view is provided by the observations of a marked upregulation of uterine oxytocin receptors before term (Fuchs et al., 1982). The oxytocin receptor gene may form part of a gene 'cassette' (Lefebvre et al., 1995), induction of which is essential for the successful initiation of labour. An important advance in our understanding of the role of oxytocin in parturition was the demonstration that the decidua is a major site of oxytocin gene expression (Lefebvre et al., 1992; Chibbar et al., 1993), raising the possibility of paracrine effects of oxytocin. However, in humans, only the mRNA has been identified and so paracrine effects remain speculative.

The oxytocin receptor couples to Gq $\alpha$ proteins and the inositol triphosphate pathway, leading to increases in intracellular calcium and phosphorylation of the myosin light chains. In addition, the oxytocin receptor can activate MAPK (Ohmichi et al., 1995; Molnar et al., 1999). Thus, activation of the oxytocin receptor leads to a shift in the intracellular microenvironment from quiescence to contractility. This effect is amplified by important intracellular crosstalk between the oxytocin and $\mathrm{CRH}$ receptors. At term, but not pre-term, oxytocin activates protein kinase C (PKC), which phosphorylates the $\mathrm{CRH}$ receptor at one or more specific Ser or Thr residues, resulting in receptor desensitization and reduction in adenylate cyclase activation (Grammatopoulos et al., 1996; Grammatopoulos and Hillhouse, 1999). In addition, activation of PKC results in a reduction in membrane-bound guanyl cyclase activity and cGMP production, thereby neutralizing relaxation pathways at multiple levels. This activation of PKC occurs only in term myometrium, possibly due to the increased number of oxytocin receptors. Recently, we have been able to show that this PKC-induced desensitization is mediated predominantly via the $\mathrm{CRH}-1 \beta$ receptor subtypes (D. K. Grammatopoulos, M. Levine and E. W. Hillhouse, unpublished).

At term, CRH or urocortin or both may enhance myometrial contractility, as both augment the myometrial contractile response to $\mathrm{PGF}_{2 \alpha}$ and oxytocin (Benedetto et al., 1994; Petraglia et al., 1999). Furthermore, urocortin promotes myometrial contractility via activation of the MAPK signalling pathways, an effect mediated via activation of the $1 \alpha$ and $2 \beta$ receptor subtypes (Grammatopoulos et al., 2000). These observations are indicative of a dual role for $\mathrm{CRH}$ or urocortin or both. Such a mechanism would enable these peptides to promote myometrial relaxation during most of gestation but to enhance the contractile response of the myometrium at term. This model places $\mathrm{CRH}$ in a central role in co-ordinating the smooth transition from a state of quiescence to one of contractility. 


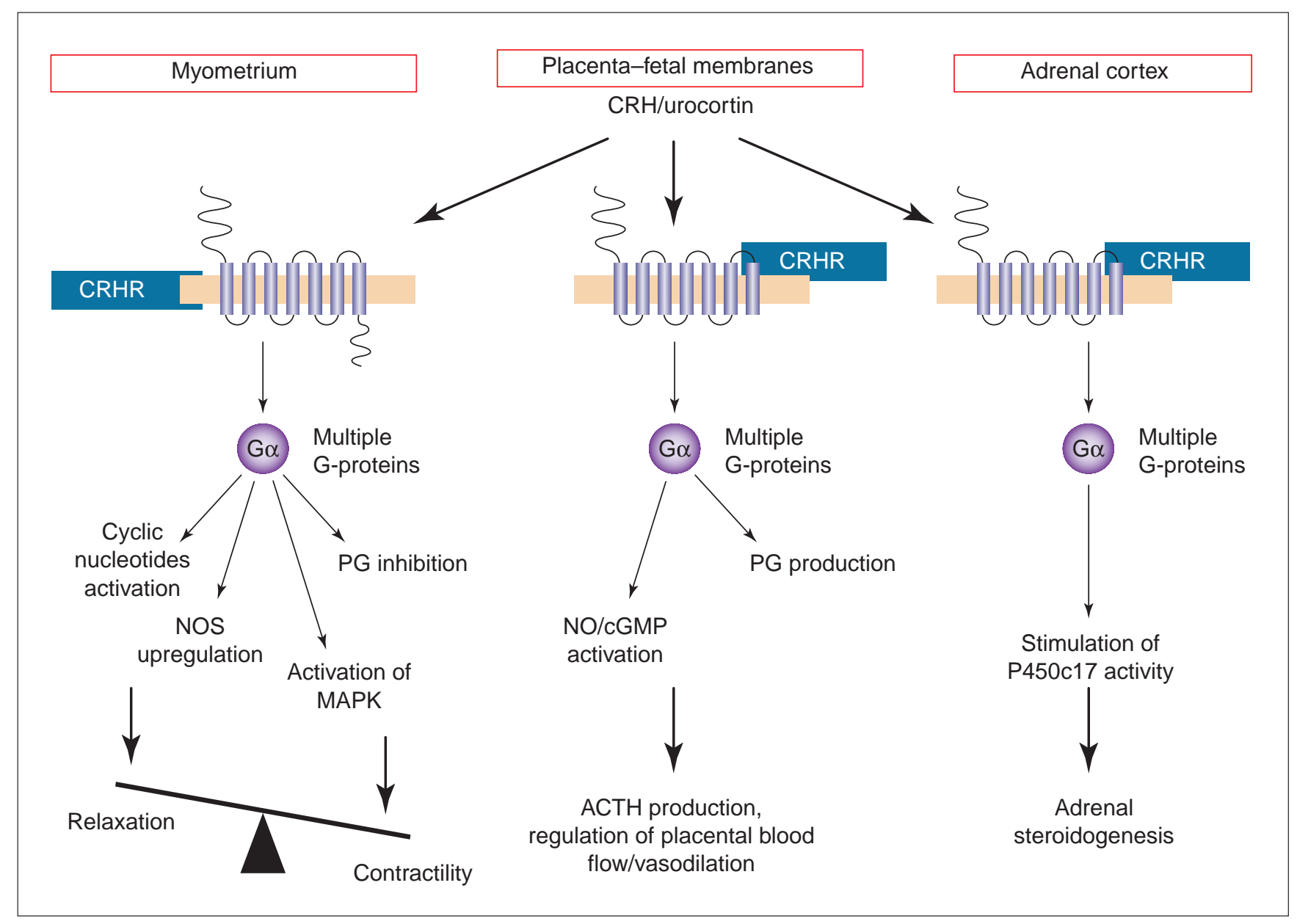

Fig. 3. Proposed signalling cascades activated by corticotrophin releasing hormone $(\mathrm{CRH})$ ligands in fetomaternal tissues during human pregnancy. CRHR: CRH receptor; NOS: nitric oxide synthase; PG: prostaglandin; MAPK: MAP kinase; ACTH: adrenocorticotrophic hormone.

\section{Role of CRH and related peptides in placenta, fetal membranes and adrenal glands}

In the placenta and fetal membranes, $\mathrm{CRH}$ does not signal via adenylate cyclase; however, it can activate $\operatorname{Go} \alpha$ and Gq $\alpha$ in both tissues, and also Gz $\alpha$ in the placenta (Karteris et al., 2000). In addition, CRH stimulates the production of inositol triphosphates (Karteris et al., 2000), which may act as a signal to prostaglandin biosynthesis secondary to induction of type 2 cyclo-oxygenase (Jones and Challis, 1989). This is significant as $\beta$ agonists that activate adenylyl cyclase and generate CAMP in these tissues also upregulate COX 2 expression (Warrick et al., 1985). This dichotomy may prove to have an important functional consequence but at the moment this remains elusive. In the placenta, $\mathrm{CRH}$ also stimulates the production of adrenocorticotrophic hormone $(\mathrm{ACTH})$ in an analogous manner to that in the pituitary gland, but not via activation of cAMP (Petraglia et al., 1987).

$\mathrm{CRH}$ and urocortin also play an important role in regulating blood flow in the placenta via activation of the nitric oxide-cGMP system (Clifton et al., 1995; Leitch et al.,
1998). This effect may be mediated via activation of type 2 receptors, as urocortin is more potent than $\mathrm{CRH}$ in inducing placental vasodilatation. This is in contrast to the myometrium in which $\mathrm{CRH}$ also activates the nitric oxide-cGMP system via type 1 receptors and promotes myometrial relaxation (Aggelidou et al., 2002).

In the fetal adrenal gland, CRH stimulates P450c17 activity via generation of inositol triphosphates leading to dihydroepiandrostenedione production (Smith et al., 1998; Chakravorty et al., 1999). The latter is the principal substrate for placental oestrogen synthesis, which has a profound influence on $\mathrm{CRH}$ receptor subtype expression (E. W. Hillhouse and D. K. Grammatopoulos, unpublished). Thus it is possible that $\mathrm{CRH}$ itself may indirectly influence tissue expression of $\mathrm{CRH}$ receptors and, hence, its own biological actions during gestation. Whether the effects of oestrogen are due to actions on promoter activity, splicing enzymes or a combination of the two is currently unknown. Oestrogen also has profound effects on myometrial G protein expression and generation of intracellular second messengers (Zervou et al., 2002). 


\section{Conclusion}

During pregnancy and labour there is a progressive increase in maternal plasma concentrations of $\mathrm{CRH}$, which can be used as a marker of pre-term delivery. This could be interpreted as $\mathrm{CRH}$ driving mechanisms leading to premature birth; however, the available evidence suggests the opposite. It appears likely that $\mathrm{CRH}$, acting via specific $\mathrm{CRH}$ receptor subtypes, dampens myometrial contractility during most of gestation (Fig. 3). Thus, CRH acts as a 'stress peptide' that is synthesized in increased amounts in 'at risk' pregnancies to try to prevent premature myometrial contractions. However, at term, these 'protective mechanisms' are disabled under the influence of the oxytocin receptor, thereby allowing $\mathrm{CRH}$, via alternate specific receptor subtypes, to participate in the mechanisms leading to expulsion of the fetus.

This work was supported by grants from The Wellcome Trust, Action Research, The Sir Jules Thorn Charitable Trust, BBSRC, Coventry General Charities, The WPH Charitable Trust and The Diabetes Medical Research Fund. D. K. Grammatopoulos is a Wellcome Career Development Fellow and E. W. Hillhouse is The WPH Charitable Trust Chair of Medicine.

\section{References}

Key references are identified by asterisks.

Aggelidou E, Hillhouse E and Grammatopoulos D (2002) Up-regulation of nitric oxide synthase and modulation of the guanylate cyclase activity by corticotropin-releasing hormone but not urocortin II or urocortin III in cultured human pregnant myometrial cells Proceedings National Academy of Sciences USA 99 3300-3305

Behan D, Linton E and Lowry P (1989) Isolation of the human plasma corticotropin-releasing hormone binding protein Journal of Endocrinology 122 23-31

Benedetto C, Petraglia F, Marozio L, Chiarolini L, Florio P, Genazzani AR and Massobrio M (1994) Corticotropin-releasing hormone increases prostaglandin F2 alpha activity on human myometrium in vitro. American Journal of Obstetrics and Gynecology 171 126-131

*Campbell E, Linton E, Wolfe C, Scraggs P, Jones M and Lowry P (1987) Plasma corticotropin-releasing hormone concentrations during pregnancy and parturition Journal of Clinical Endocrinology and Metabolism 64 1054-1059

Chakravorty A, Mesiano S and Jaffe RB (1999) Corticotropin-releasing hormone stimulates P450 17 $\alpha$-hydroxylase/17,20-lyase in human fetal adrenal cells via protein kinase C Journal of Clinical Endocrinology and Metabolism 84 3732-3738

*Challis J, Matthews S, Gibb W and Lye S (2000) Endocrine and paracrine regulation of birth at term and preterm Endocrine Reviews 21 514-550

Chen R, Lewis K, Perrin M and Vale W (1993) Expression cloning of a human corticotropin-releasing-factor receptor Proceedings National Academy of Sciences USA 90 8967-8971

Chibbar R, Miller F and Mitchell B (1993) Synthesis of oxytocin in amnion, chorion and decidua may influence the timing of human parturition Journal of Clinical Investigation 91 185-192

Clifton V, Read M, Leitch I, Giles W, Boura A, Robinson P and Smith R (1995) Corticotropin-releasing hormone-induced vasodilation in the human fetal-placental circulation: involvement of the nitric oxidecyclic guanosine $3^{\prime}, 5^{\prime}$-monophosphate pathway Journal of Clinical Endocrinology and Metabolism 80 2888-2893

Clifton V, Telfer J, Thompson A, Cameron I, Teoh T, Lye S and Challis J (1998) Corticotropin-releasing hormone and proopiomelanocortinderived peptides are present in human myometrium Journal of Clinical Endocrinology and Metabolism 83 3716-3721
Clifton V, Quing G, Murphy V, Schwartz J, Madsen G and Smith R (2000) Localization and characterization of urocortin during human pregnancy Placenta 21 782-788

Donaldson C, Sutton S, Perrin M, Corrigan A, Lewis K, Rivier J, Vaughan J and Vale W (1996) Cloning and characterisation of human urocortin Endocrinology 137 2167-2170

Florio P, Franchini A, Reis FM, Pezzani I, Ottaviani E and Petraglia F (2000) Human placenta, chorion, amnion and decidua express different variants of corticotropin-releasing factor receptor messenger RNA Placenta 21 32-37

Fuchs AR, Fuchs F, Husslein P, Soloff MS and Fernstrom MJ (1982) Oxytocin receptors and human parturition: a dual role for oxytocin in the initiation of labour Science 215 1396-1398

Goland R, Wardlaw S, Stark I, Brown L and Frantz A (1986) High levels of corticotropin-releasing hormone immunoreactivity in maternal and fetal plasma during pregnancy Journal of Clinical Endocrinology and Metabolism 63 1199-1203

Goland RS, Tropper PJ, Warren WB, Stark RI, Jozak SM and Conwell IM (1995) Concentrations of corticotrophin-releasing hormone in the umbilical-cord blood of pregnancies complicated by pre-eclampsia Reproduction, Fertility and Development 7 1227-1230

*Grammatopoulos D and Hillhouse E (1999) Role of corticotropin-releasing hormone in the onset of labour Lancet 354 1546-1549

Grammatopoulos D, Milton NG and Hillhouse EW (1994) The human myometrial $\mathrm{CRH}$ receptor: $\mathrm{G}$ proteins and second messengers Molecular and Cellular Endocrinology 99 245-250

Grammatopoulos D, Stirrat GM, Williams SA and Hillhouse EW (1996) The biological activity of the corticotropin-releasing hormone receptoradenylate cyclase complex in human myometrium is reduced at the end of pregnancy Journal of Clinical Endocrinology and Metabolism 81 745-751

Grammatopoulos D, Dai Y, Chen J, Karteris E, Papadopoulou N, Easton AJ and Hillhouse EW (1998) Human CRH receptor: differences in subtype expression between pregnant and non-pregnant myometrium Journal of Clinical Endocrinology and Metabolism 83 2539-2544

Grammatopoulos D, Dai Y, Randeva H, Levine M, Karteris E, Easton A and Hillhouse $\mathbf{E}$ (1999) A novel spliced variant of the type 1 corticotropinreleasing hormone $(\mathrm{CRH})$ receptor with a deletion in the 7 th transmembrane domain present in the human pregnant term myometrium and fetal membranes Molecular Endocrinology 13 2189-2202

${ }^{*}$ Grammatopoulos D, Randeva H, Levine MA, Katsanou E and Hillhouse EW (2000) Urocortin, but not corticotropin-releasing hormone (CRH), activates the mitogen-activated protein kinase signal transduction pathway in human pregnant myometrium: an effect mediated via R1 alpha and R2 beta CRH receptor subtypes and stimulation of Gqproteins Molecular Endocrinology 14 2076-2091

Gravanis A, Makrigiannakis A, Zoumakis E and Margioris A (2001) Endometrial and myometrial corticotropin-releasing hormone (CRH): its regulation and possible roles Peptides 22 785-793

Hillhouse E and Grammatopoulos D (2001) Characterising the corticotropin-releasing hormone $(\mathrm{CRH})$ receptors mediating $\mathrm{CRH}$ and urocortin actions during human pregnancy and labour Stress 4 235-246

Hobel C, Arora C and Korst L (1999) Corticotrophin-releasing hormone and $\mathrm{CRH}$-binding protein. Differences between patients at risk for preterm birth and hypertension Annals of the New York Academy of Science 897 54-65

Jones S and Challis J (1989) Local stimulation of prostaglandin production by corticotropin-releasing hormone in human fetal membranes and placenta Biochemical and Biophysical Research Communications 159 192-199

Karalis K, Goodwin G and Majzoub J (1996) Cortisol blockade of progesterone: a possible molecular mechanism involved in the initiation of human labor Nature Medicine 2 556-560

Karteris E, Grammatopoulos D, Dai Y, Olah KB, Ghobara TB, Easton A and Hillhouse $\mathbf{E}$ (1998) The human placenta and fetal membranes express the corticotropin-releasing hormone receptor 1alpha (CRH-1alpha) and the $\mathrm{CRH}-\mathrm{C}$ variant receptor Journal of Clinical Endocrinology and Metabolism 83 1376-1379

Karteris E, Grammatopoulos D, Randeva H and Hillhouse EW (2000) Signal 
transduction characteristics of the corticotropin-releasing hormone receptors in the feto-placental unit Journal of Clinical Endocrinology and Metabolism 85 1989-1996

Karteris E, Grammatopoulos D, Randeva HS and Hillhouse EW (2001) The role of corticotropin-releasing hormone receptors in placenta and fetal membranes during human pregnancy Molecular Genetics and Metabolism 72 287-296

Korebrits C, Ramirez M, Watson L, Brinkman E, Bocking A and Challis J (1998) Maternal corticotropin-releasing hormone is increased with impending preterm birth Journal of Clinical Endocrinology and Metabolism 83 1585-1591

Lefebvre D, Giaid A, Bennett H, Lariviere R and Zingg HH (1992) Oxytocin gene expresion in the rat uterus Science 256 1553-1555

Lefebvre DL, Piersanti M, Bai XH, Chen ZQ and Lye SJ (1995) Myometrial transcriptional regulation of the gap junction gene, connexin-43 Reproduction, Fertility and Development 7 603-611

Leitch I, Boura A, Botti C, Read M, Walters W and Smith R (1998) Vasodilator actions of urocortin and related peptides in the human perfused placenta in vitro. Journal of Clinical Endocrinology and Metabolism 83 4510-4513

Lewis K, Perrin M, Blount A et al. (2001) Identification of urocortin III, an additional member of the corticotropin-releasing factor (CRF) family with high affinity for CRF2 receptor Proceedings National Academy of Sciences USA 98 7570-7575

Liggins G (1976) Adrenocortical-related maturational events in the fetus American Journal of Obstetrics and Gynecology 126 931-941

Lovenberg TW, Liaw CW, Grigoriadis DE, Clevenger W, Chalmers DT, De Souza EB and Oltersdorf T (1995) Cloning and characterization of a functionally distinct corticotropin-releasing factor receptor subtype from rat brain Proceedings National Academy of Sciences USA 92 836-840

*McLean M, Bisits A, Davies J, Woods R, Lowry P and Smith R (1995) A placental clock controlling the length of human pregnancy Nature Medicine 1460-463

Meyer AH, Ullmer C, Schmuck K, Morel C, Wishart W, Lubbert $\mathbf{H}$ and Engels P (1997) Localization of the human CRF2 receptor to 7p21-p15 by radiation hybrid mapping and FISH analysis Genomics 40 189-190

Molnar M, Rigo J, Romero R and Hertelendy F (1999) Oxytocin activates mitogen-activated protein kinase and up-regulates cyclooxygenase-2 and prostaglandin production in human myometrial cells American Journal of Obstetrics and Gynecology 181 42-49

Nishimori K, Young LJ, Guo Q, Wang Z, Insel TR and Matzuk MM (1996) Oxytocin is required for nursing but is not essential for parturition or reproductive behavior Proceedings National Academy of Sciences USA $9311699-11704$

Ohmichi M, Koike K, Nohara A, Kanda Y, Sakamoto Y, Zhang ZX, Hirota K and Miyake A (1995) Oxytocin stimulates mitogen-activated protein kinase activity in cultured human puerperal uterine myometrial cells Endocrinology 136 2082-2087

Petraglia F, Sawchenko PE, Rivier J and Vale W (1987) Evidence for local stimulation of ACTH secretion by corticotropin-releasing factor in human placenta Nature 328 717-719

Petraglia F, Florio P, Gallo R, Simincinni T, Saviozzi M, Di Blasio A, Vaughan J and Vale W (1996) Human placenta and fetal membranes express human urocortin mRNA and peptide Journal of Clinical Endocrinology and Metabolism 81 3807-3810

Petraglia F, Florio P, Benedetto C et al. (1999) Urocortin stimulates placental adrenocorticotropin and prostaglandin release and myometrial contractility in vitro. Journal of Clinical Endocrinology and Metabolism 84 1420-1423

Pollard JK and Mitchell MD (1996) Intrauterine infection and the effects of inflammatory mediators on prostaglandin production by myometrial cells from pregnant women American Journal of Obstetrics and Gynecology 174 682-686

Polymeropoulos MH, Torres R, Yanovski JA, Chandrasekharappa SC and Ledbetter DH (1995) The human corticotropin-releasing factor receptor (CRHR) gene maps to chromosome 17q12-q22 Genomics 28 123-124

Potter E, Behan D, Fischer W, Linton E, Lowry P and Vale W (1991) Cloning and characterization of the cDNAs for human and rat corticotropinreleasing factor binding proteins Nature 349 423-426

Randeva H, Karteris E, Grammatopoulos D, Jaffe R and Hillhouse E (2001) Expression and coupling characteristics of the $\mathrm{CRH}$ and orexin type 2 receptors in human fetal adrenals Journal of Clinical Endocrinology and Metabolism 86 4512-4519

Reyes T, Lewis K, Perrin M et al. (2001) Urocortin II: a member of the corticotropin-releasing factor (CRF) neuropeptide family that is selectively bound by type 2 CRF receptors Proceedings National Academy of Sciences USA 98 2843-2848

Riley S, Walton J, Herlick J and Challis J (1991) The localization and distribution of corticotropin-releasing hormone in the placenta and fetal membranes throughout gestation Journal of Clinical Endocrinology and Metabolism 72 1001-1007

Romero R, Sibai BM, Sanchez-Ramos L et al. (2000) An oxytocin receptor antagonist (atosiban) in the treatment of preterm labor: a randomized, double-blind, placebo-controlled trial with tocolytic rescue American Journal of Obstetrics and Gynecology 183 1173-1183

Sasaki A, Shinkawa O, Margioris A et al. (1987) Immunoreactive corticotropin-releasing hormone in human plasma during pregnancy, labor and delivery Journal of Clinical Endocrinology and Metabolism 64 224-229

Smith R, Mesiano S, Chan EC, Brown S and Jaffe R (1998) Corticotropinreleasing hormone directly and preferentially stimulates dehydroepiandrosterone sulfate secretion by human fetal adrenal cortical cells Journal of Clinical Endocrinology and Metabolism 83 2916-2920

Thorburn G and Challis J (1979) Endocrine control of parturition Physiological Reviews 59 863-918

Valenzuela GJ, Sanchez-Ramos L, Romero R et al. (2000) Maintenance treatment of preterm labor with the oxytocin antagonist atosiban. The atosiban PTL-098 study group American Journal of Obstetrics and Gynecology 182 1184-1190

Vaughan J, Donaldson C, Bittencourt J et al. (1995) Urocortin, a mammalian neuropeptide related to fish urotensin and corticotropinreleasing factor Nature 378 287-292

Warren W and Silverman A (1995) Cellular localization of corticotrophin releasing hormone in the human placenta, fetal membranes and decidua Placenta 16 147-156

Warren W, Patrick S and Goland R (1992) Elevated maternal plasma corticotropin-releasing hormone levels in pregnancies complicated by preterm labor American Journal of Obstetrics and Gynecology $\mathbf{1 6 6}$ 1198-1204

Warrick C, Skinner K, Mitchell BF and Challis JR (1985) Relation between cyclic adenosine monophosphate and prostaglandin output by dispersed cells from human amnion and decidua American Journal of Obstetrics and Gynecology 153 66-71

Young WS, III, Shepard E, Amico J, Hennighausen L, Wagner KU, LaMarca ME, McKinney C and Ginns El (1996) Deficiency in mouse oxytocin prevents milk ejection, but not fertility or parturition Journal of Neuroendocrinology 8 847-853

Zervou S, Karteris E, Hillhouse E and Old R (2002) Steroids mediate expression of membrane-bound and cytoplasmic proteins in human myometrial cells Molecular Human Reproduction 8 597-605 